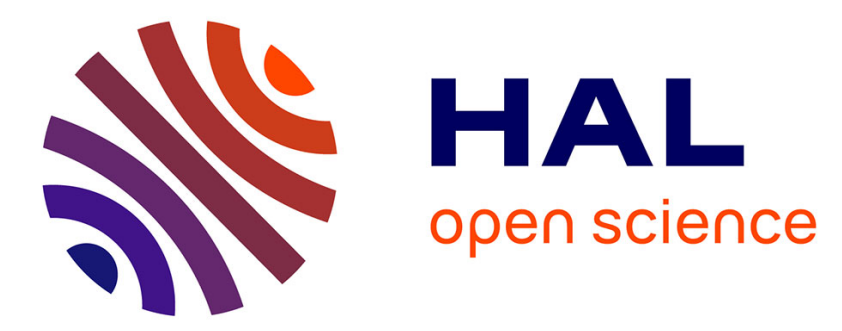

\title{
Catalytic etherification of glycerol with short chain alkyl alcohols in the presence of Lewis acids
}

Fei Liu, Karine de Oliveira Vigier, M. Pera-Titus, Yannick Pouilloux, Jean-Marc Clacens, Floryan de Campo, François Jérôme

\section{To cite this version:}

Fei Liu, Karine de Oliveira Vigier, M. Pera-Titus, Yannick Pouilloux, Jean-Marc Clacens, et al.. Catalytic etherification of glycerol with short chain alkyl alcohols in the presence of Lewis acids. Green Chemistry, 2013, 15, pp.901-909. 10.1039/c3gc36944g . hal-00859532

\section{HAL Id: hal-00859532 https://hal.science/hal-00859532}

Submitted on 16 Sep 2014

HAL is a multi-disciplinary open access archive for the deposit and dissemination of scientific research documents, whether they are published or not. The documents may come from teaching and research institutions in France or abroad, or from public or private research centers.
L'archive ouverte pluridisciplinaire HAL, est destinée au dépôt et à la diffusion de documents scientifiques de niveau recherche, publiés ou non, émanant des établissements d'enseignement et de recherche français ou étrangers, des laboratoires publics ou privés. 


\title{
Green Chemistry
}

\section{Catalytic etherification of glycerol with short chain alkyl alcohols in the presence of Lewis acids $\dagger$}

\author{
Fei Liu, ${ }^{a}$ Karine De Oliveira Vigier, ${ }^{a}$ Marc Pera-Titus, ${ }^{b}$ Yannick Pouilloux, ${ }^{a}$ \\ Jean-Marc Clacens, ${ }^{b}$ Floryan Decampo*b and François Jérôme ${ }^{\star a}$
}

Received 3rd December 2012, Accepted 28th January 2013

DOI: $10.1039 / \mathrm{c} 3$ gc36944g

www.rsc.org/greenchem

\begin{abstract}
Here we report the homogeneously-catalyzed etherification of glycerol with short chain alkyl alcohols. Among the large variety of Brønsted and Lewis acids tested, we show here that metal triflates are not only the most active but are also capable of catalyzing this reaction with an unprecedented selectivity. In particular, in the presence of $\mathrm{Bi}(\mathrm{OTf})_{3}$, the targeted monoalkylglyceryl ethers were obtained with up to $70 \%$ yield. Although tested Brønsted acids were also capable of catalyzing the etherification of glycerol with alkyl alcohols, they were found however less active and less selective than $\mathrm{Bi}(\mathrm{OTf})_{3}$. By means of counter experiments, we highlighted that the high activity and selectivity of $\mathrm{Bi}(\mathrm{OTf})_{3}$ may rely on a synergistic effect between $\mathrm{Bi}(\mathrm{OTf})_{3}$ and triflic acid, a Brønsted acid that can be released by in situ glycerolysis of $\mathrm{Bi}(\mathrm{OTf})_{3}$. The scope of this methodology was also extended to other polyols and, in all cases, the monoalkylpolyol ethers were conveniently obtained with fair to good yields.
\end{abstract}

\section{Introduction}

With an annual production of about 14 million tons in 2011, surfactants represent a huge market with a turnover estimated around 23 billion US dollars per year. ${ }^{1}$ Surfactants nowadays exhibit a broad range of applications and are mainly used in three key markets which are detergents, personal care and other industrial applications (paints, coating, cleaning, etc.).

Surfactants are typically classified according to the charge on their hydrophilic head into four different categories: nonionic, anionic, cationic and amphoteric. It must be noted that more than $80 \%$ of the volume of surfactants are of the nonionic or anionic types.

Historically, the production of surfactants from petrochemicals has been favored over oleochemicals and still represents the major part. In recent years, the continuous increase of the fossil oil price has boosted the research and development on renewable resources such as oleochemicals, carbohydrates or organic acids. ${ }^{2}$ Few studies have recently pointed out that the use of such feedstocks has the potential to significantly reduce

\footnotetext{
${ }^{a}$ Institut de Chimie des Milieux et Matériaux de Poitiers, CNRS/Université de Poitiers/ENSIP, 1 rue Marcel Doré, 86022 Poitiers, France.

E-mail: francois.jerome@univ-poitiers.fr; Fax: +33 5494533 49; Tel: +33 549454052

${ }^{b}$ Eco-Efficient Products and Processes Laboratory, Unité Mixte de Recherche UMI 3464 CNRS/RHODIA, 3966 Jin Du Road, Shanghai 201108, China.

E-mail: floryan.decampo@ap.rhodia.com; Fax: +86 21 54425911; Tel: +862124089391

†Electronic supplementary information (ESI) available. See DOI: $10.1039 / \mathrm{c} 3 g \mathrm{gc} 36944 \mathrm{~g}$
}

the green house gases emissions in surfactant industries. ${ }^{3}$ Of course, such a benefit can only be achieved by using sustainable feedstocks that are converted through high eco-efficient processes while the targeted bio-based surfactants should have an acceptable cost performance balance.

Surfactants are a class of molecules bearing a hydrophobic and a hydrophilic part, also so-called the tail and head, respectively. Renewably-sourced hydrophobic moieties are usually derived from tallow triglycerides that can be issued either from an animal or vegetal origin. Nowadays, a wide variety of fatty acids with different chain lengths are commercially produced from different feedstocks such as palm oil, rapeseed, soybean or coconut. These fatty acids can be then transformed into alcohols or amines or used directly to prepare surfactants. ${ }^{4}$ Owing to their large availability, fatty derivatives allowed renewably-sourced hydrophobic moieties to grow significantly in surfactants production to nowadays represent almost half of the volumes.

On the other hand, a particular attention has been also given to the search of renewably sourced hydrophiles in order to produce $100 \%$ bio-based surfactants. In particular, nonionic hydrophiles capable of replacing ethoxylated products are highly desirable. Glycerol or carbohydrates have the potential to be promising renewable hydrophiles but are only scarcely used today in the field of surfactants. ${ }^{3}$ If ester derivatives of glycerol or carbohydrates can be easily prepared, their performances and especially their stabilities compared to ether derivatives are however not acceptable in many applications.

For this reason, much effort has been made towards the synthesis of more robust bio-based surfactants through 
etherification or reductive amination of polyols for instance. In this context, catalytic synthesis of glycerol ethers has received considerable attention due to the robustness of these chemicals and the very attractive price of glycerol $\left(<0.6 € \mathrm{~kg}^{-1}\right)$, a co-product of the vegetable oil industry. In particular, alkyl (poly)glyceryl ethers have promising applications in many industrial fields. ${ }^{5}$ For instance, they nowadays enter in the composition of deodorants, detergents, oily foaming aerosols, cleaning cosmetics, hair dyeing agents, surface active agents, among many other applications. However, one should mention that glycerol is scarcely used in the synthesis of such surfactants and more reactive chemicals such as glycidol, epychlorhydrine are generally preferred in order to get acceptable yields to the desired alkyl (poly)glyceryl ethers. The price and toxicity of these precursors however dramatically limit the industrial emergence of these non-anionic surfactants. Hence, few groups have attempted the synthesis of alkyl (poly)glyceryl ethers directly from glycerol, a renewable, cheap and safe organic building block.

Behr, ${ }^{6}$ Weckhuysen ${ }^{7}$ and others ${ }^{8}$ have shown that synthesis of glycerol ethers can be achieved by catalytic telomerization of glycerol with butadiene in the presence of palladium-phosphine complexes affording the corresponding unsaturated glycerol monoethers with fair to good yields. Alternatively, Lemaire and co-workers have recently reported the synthesis of glycerol ethers by reductive alkylation of either aldehydes or carboxylic acids in the presence of $\mathrm{Pd} / \mathrm{C}$ and fair to good yields are also reported. ${ }^{9}$ The direct acid-catalyzed etherification of glycerol with alkyl alcohols is even more attractive since it avoids the use of transition metals. In this context, most of the works have been dedicated to the etherification of glycerol with activated alcohols such as benzyl or tertiobutyl alcohols in the presence of various acid catalysts. ${ }^{10}$ Unfortunately, alkyl alcohols are not eligible in such processes making this route not viable for the synthesis of surfactants. We and others have recently investigated the acid-catalyzed etherification of glycerol with alkyl alcohols. ${ }^{11}$ Although formation of glyceryl ethers has been observed, one should mention that these processes suffer from an important lack of selectivity requiring a complex and energy-consuming work-up.

Clearly the industrial emergence of alkyl glyceryl ethers nowadays requires deeper investigations in order to better control the selectivity of this reaction. In these processes, few issues need to be addressed. First it is necessary to avoid the side dehydration and self-etherification of glycerol and alkyl alcohols, side products that are very difficult to separate from the reaction medium. Secondly, polyetherification of glycerol with alkyl alcohols is also unwanted since these products do not have the desired surfactant properties. Here, we wish to report a selective route capable of providing alkyl glyceryl ethers with high yields directly from glycerol and alkyl alcohols with a chain length within the range of 4-6 atoms of carbon. Note that both chemicals are nowadays available from biomass, either from vegetable oils or through the fermentation of carbohydrates. Owing to their low foaming properties, these short chain alkyl glyceryl ethers are nowadays recognized as promising molecules especially for the home and personal care market but they also have the potential to act as a safe defoamer in various industrial applications.

\section{Experimental}

\section{Chemicals}

All chemicals were used as received. Glycerol (Stearinerie Dubois, 99\%), 1-butanol (Acros, 99\%), 1-pentanol (Prolabo), 1-hexanol (Merck), 1,2-propanediol (Fluka, >99\%), 1,3propanediol (Acros, 98\%) 1,1,1-tris(hydroxymethyl)ethane (Acros, 97\%) were used for all syntheses. All metal triflates and triflimidates were kindly provided by Rhodia-Solvay. Metal chlorides were purchased from Strem Chemicals.

\section{Typical procedure for the catalytic etherification of glycerol with short chain alcohols}

In a typical procedure, glycerol $(40 \mathrm{mmol})$ and $n$-butanol (10 mmol) were mixed together in the presence of an acid catalyst $(6.5 \mathrm{~mol} \%)$ prior to heating at $150{ }^{\circ} \mathrm{C}$ for $24 \mathrm{~h}$ in a sealed glass reactor. Note that the solution occupies $80 \%$ of the volume of the reactor in order to limit the presence of $n$ butanol in the gas phase. At the end of the reaction, the reactor was opened when it was still hot and a sample was taken off for analysis.

\section{Analytical methods}

Gas chromatography analyses were performed on a Varian 3350 equipped with an on column injector $\left(50{ }^{\circ} \mathrm{C}\right)$, an FID detector $\left(300{ }^{\circ} \mathrm{C}\right)$ and an HT5 column $(25 \mathrm{~m} \times 0.32 \mathrm{~mm} \times$ $0.1 \mu \mathrm{m})$. Prior to analysis, the sample was silylated as follows: typically, to $30 \mathrm{mg}$ of the reaction medium was added $100 \mu \mathrm{l}$ of diglyme (internal standard), $500 \mu \mathrm{l}$ of pyridine and $250 \mu \mathrm{l}$ of hexamethyldisilazane (HMDS). The mixture was then heated and stirred vigorously to dissolve all products. Then, $200 \mu \mathrm{l}$ of chlorotrimethylsilane (TMSCl) was added and the resulting solution was kept at room temperature for 10 minutes. Next, the sample was centrifugated prior to performing the analysis. NMR spectra were recorded on BRUKER ADVANCE DPX 400 spectrometers at $400.13 \mathrm{MHz}$ for ${ }^{1} \mathrm{H}$ and $100.6 \mathrm{MHz}$ for ${ }^{13} \mathrm{C}$.

\section{Characterization methods}

Monobutylglyceryl ethers (B1G1) are produced as a mixture of two regioisomers with the main etherification on the primary hydroxyl group. Exact determination of the regioselectivity is difficult to determine in this case due to the overlapping of the two regioisomer retention times in gas chromatography. Below are provided the analytical data for the 1-monobutylglyceryl ethers.

${ }^{1} \mathrm{H}$ NMR (400 MHz, $\left.\mathrm{CDCl}_{3}, \mathrm{ppm}\right): 0.90(\mathrm{t}, J=7.2 \mathrm{~Hz}, 3 \mathrm{H}$, $\left.-\mathrm{CH}_{3}\right), 1.29-1.39\left(\mathrm{~m}, 2 \mathrm{H},-\mathrm{CH}_{2}-\right), 1.51-1.58\left(\mathrm{~m}, 2 \mathrm{H},-\mathrm{CH}_{2}^{-}\right)$, 2.92-3.21 (m, 2H, 2× -OH), 3.42-3.51 (m, 4H, 2×- $\mathrm{OCH}_{2}-$ ), $3.57-3.68\left(\mathrm{~m}, 2 \mathrm{H},-\mathrm{CH}_{2}-\mathrm{OH}\right), 3.84(\mathrm{~m}, 1 \mathrm{H},-\mathrm{CH}-\mathrm{O}) ;{ }^{13} \mathrm{C} \mathrm{NMR}$ (100 MHz, $\left.\mathrm{CDCl}_{3}, \mathrm{ppm}\right): 13.9\left(-\mathrm{CH}_{3}\right), 19.3\left(-\mathrm{CH}_{2}\right), 31.6\left(-\mathrm{CH}_{2}\right)$, $64.3\left(-\mathrm{OCH}_{2}\right), 70.6(-\mathrm{OCH}), 71.5\left(-\mathrm{OCH}_{2}-\right), 72.3\left(-\mathrm{OCH}_{2}\right)$. Note 
that similar NMR spectra were collected in the literature for monopentyl- and monohexyl-glyceryl ethers. ${ }^{9 c}$ Only integration of the fatty chain differs between each spectrum.

Mono ethers obtained from 1,2-propylene glycol (mixture of regioisomer): ${ }^{1} \mathrm{H}$ NMR (400 $\left.\mathrm{MHz}, \mathrm{CDCl}_{3}, \mathrm{ppm}\right): 0.91(\mathrm{t}, J=$ $\left.7.2 \mathrm{~Hz}, 3 \mathrm{H},-\mathrm{CH}_{3}\right), 1.09$ and $1.13(\mathrm{~d}, J=6.4 \mathrm{~Hz}$ and $J=6.0 \mathrm{~Hz}$, $\left.2 \mathrm{H},-\mathrm{CH}_{2}\right), 1.32-1.41\left(\mathrm{~m}, 2 \mathrm{H},-\mathrm{CH}_{2}-\right), 1.52-1.59(\mathrm{~m}, 2 \mathrm{H}$, $-\mathrm{CH}_{2}-$ ), 2.61 (bs, 1H, $\left.-\mathrm{OH}\right), 3.17-3.51\left(\mathrm{~m}, 4 \mathrm{H}, 2 \times-\mathrm{CH}_{2}\right.$ ), 3.53-3.58 and 3.90-3.98 (m, 1H, -CH-O). ${ }^{13} \mathrm{C}$ NMR (100 MHz, $\left.\mathrm{CDCl}_{3}, \mathrm{ppm}\right)$ : 13.7 and $13.9\left(-\mathrm{CH}_{3}\right), 15.9$ and $18.6\left(-\mathrm{CH}_{3}\right), 19.3$ and $19.4\left(-\mathrm{CH}_{2}\right), 31.7$ and $32.1\left(-\mathrm{OCH}_{2}\right), 66.3$ and 71.1 $\left(-\mathrm{OCH}_{2}\right), 66.4$ and $75.7(-\mathrm{OCH}), 68.6$ and $76.3\left(-\mathrm{OCH}_{2}\right)$.

Mono ethers obtained from 1,3-propanediol: ${ }^{1} \mathrm{H}$ NMR (400 MHz, $\left.\mathrm{CDCl}_{3}, \mathrm{ppm}\right): 0.89$ (t, $J=7.2 \mathrm{~Hz}, 3 \mathrm{H}, \mathrm{CH}_{3}$ ), 1.29-1.39 $\left(\mathrm{m}, 2 \mathrm{H},-\mathrm{CH}_{2}-\right), 1.50-1.57\left(\mathrm{~m}, 2 \mathrm{H},-\mathrm{CH}_{2}-\right), 1.78-1.84(\mathrm{~m}, 2 \mathrm{H}$, $-\mathrm{CH}_{2}-$ ), 2.61 (bs, $\left.1 \mathrm{H},-\mathrm{OH}\right), 3.42\left(\mathrm{t}, J=6.8 \mathrm{~Hz}, 2 \mathrm{H},-\mathrm{CH}_{2}-\mathrm{O}-\right.$ ), $3.59\left(\mathrm{t}, J=5.6 \mathrm{~Hz}, 2 \mathrm{H},-\mathrm{CH}_{2}-\mathrm{O}-\right), 3.75\left(\mathrm{t}, J=5.6 \mathrm{~Hz}, 2 \mathrm{H},-\mathrm{CH}_{2}-\right.$ $\mathrm{OH}) .{ }^{13} \mathrm{C} \mathrm{NMR}\left(100 \mathrm{MHz}, \mathrm{CDCl}_{3}, \mathrm{ppm}\right): 13.9\left(-\mathrm{CH}_{3}\right), 19.3$ $\left(-\mathrm{CH}_{2}\right), 31.7\left(-\mathrm{CH}_{2}\right), \quad 32.0 \quad\left(-\mathrm{CH}_{2}\right), 62.3 \quad\left(-\mathrm{CH}_{2}-\mathrm{OH}\right), \quad 70.3$ $\left(-\mathrm{OCH}_{2}\right), 71.1\left(-\mathrm{OCH}_{2}\right)$.

Mono ethers obtained from tris(hydroxymethyl)ethane: ${ }^{1} \mathrm{H}$ NMR (400 MHz, $\left.\mathrm{CDCl}_{3}, \mathrm{ppm}\right): 0.80\left(\mathrm{~s}, 3 \mathrm{H},-\mathrm{CH}_{3}\right), 0.90(\mathrm{t}, J=$ $\left.7.4 \mathrm{~Hz}, 3 \mathrm{H},-\mathrm{CH}_{3}\right), 1.29-1.39\left(\mathrm{~m}, 2 \mathrm{H},-\mathrm{CH}_{2}-\right), 1.50-1.57(\mathrm{~m}$, $\left.2 \mathrm{H},-\mathrm{CH}_{2}-\right), 2.86(\mathrm{bs}, 2 \times-\mathrm{OH}), 3.39-3.42\left(\mathrm{~m}, 4 \mathrm{H},-\mathrm{CH}_{2}-\mathrm{O}-\right.$ $\mathrm{CH}_{2}-$ ), 3.55 (d, $\left.J=10.8 \mathrm{~Hz}, 2 \mathrm{H},-\mathrm{CH}_{2}-\mathrm{OH}\right), 3.68$ (d, $J=10.8 \mathrm{~Hz}$, $\left.2 \mathrm{H},-\mathrm{CH}_{2}-\mathrm{OH}\right) .{ }^{13} \mathrm{C} \mathrm{NMR}\left(100 \mathrm{MHz}, \mathrm{CDCl}_{3}, \mathrm{ppm}\right): 13.9\left(-\mathrm{CH}_{3}\right)$, $17.2\left(-\mathrm{CH}_{3}\right), 19.3\left(-\mathrm{CH}_{2}\right), 31.6\left(-\mathrm{CH}_{2}\right), 40.7\left(-\mathrm{CH}_{2}\right), 67.8$ $\left(2 \times-\mathrm{CH}_{2}-\mathrm{OH}\right), 71.7\left(-\mathrm{OCH}_{2}\right), 76.9\left(-\mathrm{OCH}_{2}\right)$.

Mono ethers obtained from isosorbide: ${ }^{1} \mathrm{H} \mathrm{NMR}(400 \mathrm{MHz}$, $\left.\mathrm{CDCl}_{3}, \mathrm{ppm}\right): 0.87\left(\mathrm{t}, J=7.2 \mathrm{~Hz}, 3 \mathrm{H},-\mathrm{CH}_{3}\right), 1.27-1.36(\mathrm{~m}, 2 \mathrm{H}$, $-\mathrm{CH}_{2}-$ ), 1.51-1.58 (m, 2H, $-\mathrm{CH}_{2}-$ ), 3.18 (bs, $\left.-\mathrm{OH}\right), 3.37-3.64$ $\left(\mathrm{m}, 3 \mathrm{H},-\mathrm{CH}_{2}-\right.$ and $\left.\mathrm{H}_{4}\right), 3.83-3.97\left(\mathrm{~m}, 4 \mathrm{H}, \mathrm{H}_{1}\right.$ and $\left.\mathrm{H}_{6}\right)$, $4.22-4.23\left(\mathrm{~m}, 1 \mathrm{H}, \mathrm{H}_{5}\right), 4.38\left(\mathrm{~d}, J=4 \mathrm{~Hz}, 1 \mathrm{H}, \mathrm{H}_{2}\right), 4.63(\mathrm{t}, J=$ $\left.4 \mathrm{~Hz}, 1 \mathrm{H}, \mathrm{H}_{3}\right) \cdot{ }^{13} \mathrm{C} \mathrm{NMR}\left(100 \mathrm{MHz}, \mathrm{CDCl}_{3}, \mathrm{ppm}\right): 13.8\left(-\mathrm{CH}_{3}\right)$, $19.1\left(-\mathrm{CH}_{2}\right), 31.8\left(-\mathrm{CH}_{2}\right), 69.9\left(-\mathrm{CH}_{2}\right), 70.7\left(-\mathrm{O}-\mathrm{CH}_{2}-\right), 75.8$ $\left(-\mathrm{O}_{-} \mathrm{CH}_{2}-\right), 76.5$ (-CH-), 80.0 (-CH-), $80.3\left(-{ }^{-} \mathrm{CH}^{-}\right), 88.3$ (-CH-).

\section{Results and discussion}

\section{Catalysis in the presence of Lewis acids}

In a first set of experiments, the acid-catalyzed etherification of glycerol with $n$-butanol was investigated. The reaction was first performed at $150{ }^{\circ} \mathrm{C}$ in the presence of a Lewis acid catalyst. The glycerol $/ n$-butanol molar ratio was fixed to 4 in order to limit the dimerization of $n$-butanol. The reaction progress (yield, conversion, selectivity, carbon mass balance) was monitored by gas chromatography using diglyme as an internal standard. For the sake of clarity, structures and abbreviations of the different reactants and products used in this work are illustrated in Fig. 1.

Various Lewis acids were first tested. Results are presented in Table 1 . Although a high catalyst loading (6.5 to $24 \mathrm{~mol} \%$ ) was employed, metal chlorides such as $\mathrm{AlCl}_{3}, \mathrm{FeCl}_{3}$ and $\mathrm{BiCl}_{3}$

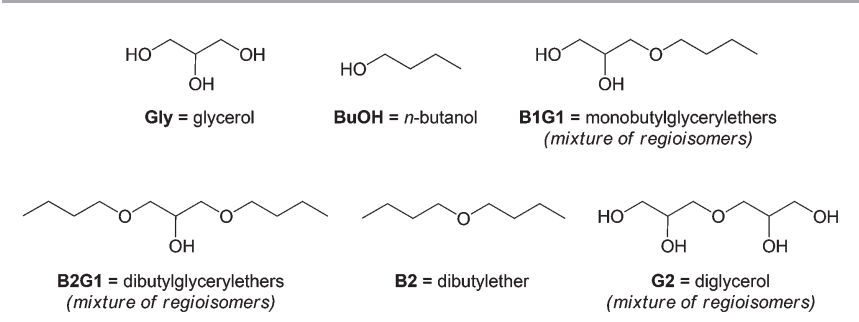

Fig. 1 Abbreviation of chemicals used in this work.

Table 1 Catalytic etherification of glycerol with $n$-butanol in the presence of Lewis acids ${ }^{a}$

$$
\overbrace{\mathrm{OH}}^{\mathrm{OH}}+\overbrace{150^{\circ} \mathrm{C} / 24 \mathrm{~h}}^{\text {Lewis acid }}
$$

\begin{tabular}{|c|c|c|c|c|c|c|c|c|c|}
\hline Entry & Catalyst & $\begin{array}{l}\text { Conv. } \\
\text { Gly (\%) }\end{array}$ & $\begin{array}{l}\text { Conv. } \\
\text { BuOH (\%) }\end{array}$ & $\begin{array}{l}{\mathrm{B} 1 G_{1}} \\
\operatorname{yield}^{b}(\%)\end{array}$ & $\begin{array}{l}\text { B2G1 } \\
\text { yield }^{b}(\%)\end{array}$ & $\begin{array}{l}\text { B2 } \\
\text { yield (\%) }\end{array}$ & $\begin{array}{l}\text { G2 } \\
\text { yield }^{b}(\%)\end{array}$ & $\begin{array}{l}\mathrm{C} \% \\
(\mathrm{BuOH})^{c}\end{array}$ & $\begin{array}{l}\text { C \% } \\
(\text { Gly })^{c}\end{array}$ \\
\hline 1 & $\mathrm{FeCl}_{3}{ }^{d}$ & 10 & 13 & 9 & 0 & 2 & 2 & 69 & 43 \\
\hline 3 & $\mathrm{BiCl}_{3}$ & 1 & 6 & 4 & 0 & 1 & 0 & - & 100 \\
\hline 4 & $\mathrm{CrCl}_{3} \cdot 6 \mathrm{H}_{2} \mathrm{O}^{f}$ & 0 & 0 & 0 & 0 & 0 & 0 & 100 & 100 \\
\hline 5 & $\mathrm{ZnCl}_{2}^{g}$ & 0 & 0 & 0 & 0 & 0 & 0 & - & - \\
\hline 6 & $\mathrm{Nd}(\mathrm{OTf})_{3}$ & 4 & 20 & 12 & 0 & 3 & 1 & 75 & 100 \\
\hline 9 & $\operatorname{In}(\text { OTf })_{3}$ & 17 & 70 & 45 & 0 & 10 & 6 & 79 & 100 \\
\hline 10 & $\mathrm{Ga}(\mathrm{OTf})_{3}$ & 23 & 80 & 62 & 2 & 9 & 6 & 91 & 93 \\
\hline 11 & $\mathrm{Al}(\mathrm{OTf})_{3}$ & 18 & 65 & 48 & 0 & 8 & 4 & 87 & 89 \\
\hline 12 & $\mathrm{Bi}(\mathrm{OTf})_{3}$ & 30 & 91 & 70 & 7 & 10 & 8 & 95 & 85 \\
\hline 13 & $\mathrm{Al}(\mathrm{TFSI})_{3}$ & 10 & 55 & 32 & 0 & 3 & 2 & 64 & 99 \\
\hline 14 & $\mathrm{Fe}(\mathrm{TFSI})_{3}$ & 6 & 52 & 17 & 0 & 4 & 1 & 40 & 71 \\
\hline 15 & $\mathrm{Bi}(\mathrm{TFSI})^{h}$ & 20 & 40 & 28 & 0 & 2 & 7 & 75 & 70 \\
\hline
\end{tabular}

${ }^{a}$ Glycerol $/ n$-butanol molar ratio $=4,150{ }^{\circ} \mathrm{C}, 24 \mathrm{~h}, 6.5$ mol\% of catalyst. ${ }^{b}$ Mixture of regioisomers. ${ }^{c}$ Carbon mass balance. ${ }^{d} 22 \mathrm{~mol} \% .{ }^{e} 16$ mol\%. $f_{13} \mathrm{~mol} \% .{ }^{g} 24 \mathrm{~mol} \% .{ }^{h}$ At $190{ }^{\circ} \mathrm{C}$. 
were poorly active in the catalytic etherification of glycerol with $n$-butanol and the targeted B1G1 were produced with 16\%, 9\% and $4 \%$ yields, respectively, after $24 \mathrm{~h}$ of reaction (entries 1-3). Additionally, at higher conversion of $n$-butanol (30\%), the selectivity to B1G1 was rather low in the presence of $\mathrm{AlCl}_{3} \cdot 6 \mathrm{H}_{2} \mathrm{O}$. Indeed, under these conditions, the $n$-butanol carbon mass balance was as low as $53 \%$ indicating the formation of side products from $n$-butanol. Note that other metal chlorides such as $\mathrm{CrCl}_{3}$ and $\mathrm{ZnCl}_{2}$, often used in acid-catalyzed dehydration of hexoses, ${ }^{12}$ were here totally inefficient, further confirming the complexity of this reaction (entries 4,5 ).

To our delight, when $6.5 \mathrm{~mol} \%$ of metal triflates were used under similar conditions, the reaction was much more selective to the desired B1G1 (Table 1, entries 6-12). In particular, in the presence of $\mathrm{Bi}(\mathrm{OTf})_{3}$, which is nowadays recognized as a "safe Lewis acid", the B1G1 were obtained with $70 \%$ yield at a conversion of $91 \%$ of $n$-butanol (entry 12). B2G2, B2 and G2 were produced in a limited amount with $7 \%, 10 \%$ and $8 \%$ yield, demonstrating that $\mathrm{Bi}(\mathrm{OTf})_{3}$ is selective $(85 \%$ of $\mathrm{B} 1 \mathrm{G} 1+$ B2G1) to alkyl glyceryl ethers. Note that the etherification of glycerol with $n$-butanol mainly occurred in the primary hydroxyl group of glycerol. Having this result in hand, other metal triflates were tested. As shown in Table 1, Al, Ga, In, Sc, Fe and Nd triflates were also active in the etherification of glycerol with $n$-butanol, although differences of activity were clearly observed. In all cases, the carbon mass balance on glycerol and $n$-butanol remained higher than $85 \%$, further confirming the greater selectivity of metal triflates as compared to that of metal chlorides. The order of activity was $\mathrm{Bi}>\mathrm{Al}>\mathrm{Ga}>$ In $>\mathrm{Sc}>\mathrm{Nd}$. All other tested metal triflates were found inefficient (see a complete list of tested metal triflates in Table 2).

Metal triflimidates $\left(\mathrm{M}(\mathrm{TFSI})_{3}\right)$ were also investigated as Lewis acids (Table 1, entries 13-15). In contrast to what was reported earlier in water, ${ }^{13}$ in our case, lower activity and

Table 2 Covalent radius of mono-, di- and trivalent cations used and their $\mathrm{p} K_{\mathrm{h}}$ values

\begin{tabular}{lllll}
\hline Entry & Cation & $\begin{array}{l}\text { Conv. } \\
\mathrm{BuOH}^{a}(\%)\end{array}$ & $\begin{array}{l}\mathrm{p} K_{\mathrm{h}} \\
\text { value }^{b}\end{array}$ & $\begin{array}{l}\text { Covalent radius } \\
\text { of cation (A) }\end{array}$ \\
\hline 1 & $\mathrm{Bi}$ & 91 & 1.09 & 1.17 \\
2 & $\mathrm{Ga}$ & 80 & 2.60 & 1.22 \\
3 & $\mathrm{Al}$ & 65 & 4.97 & 1.21 \\
4 & $\mathrm{In}$ & 70 & 4.00 & 1.42 \\
5 & $\mathrm{Sc}$ & 31 & 4.30 & 1.74 \\
6 & $\mathrm{Nd}$ & 30 & 8.00 & 2.01 \\
7 & $\mathrm{Fe}$ & 20 & 9.50 & 1.52 \\
8 & $\mathrm{La}$ & 0 & 8.50 & 2.07 \\
9 & $\mathrm{Y}$ & 0 & 7.70 & 1.90 \\
10 & $\mathrm{Ce}$ & 0 & 8.30 & 2.04 \\
11 & $\mathrm{Pr}$ & 0 & 8.10 & 2.03 \\
12 & $\mathrm{Sm}$ & 0 & 7.90 & 1.98 \\
13 & $\mathrm{Gd}$ & 0 & 8.00 & 1.96 \\
14 & $\mathrm{Zn}$ & 0 & 8.96 & 1.22 \\
15 & $\mathrm{Cu}$ & 0 & 7.53 & 1.32 \\
16 & $\mathrm{Ca}$ & 0 & 12.85 & 1.76 \\
17 & $\mathrm{Ag}$ & 0 & 12.00 & 0.45 \\
& & & &
\end{tabular}

${ }^{a}$ Collected after $24 \mathrm{~h}$ of reaction at $150{ }^{\circ} \mathrm{C}$ in the presence of $6.5 \mathrm{~mol} \%$ of metal triflate. ${ }^{b}$ Collected in water. selectivity than those achieved with metal triflates were obtained. Among all tested metal triflimidates (see the complete list in $\mathrm{ESI}+$ ), only $\mathrm{Al}(\mathrm{TFSI})_{3}$ and $\mathrm{Fe}(\mathrm{TFSI})_{3}$ were capable of producing $\mathrm{B} 1 \mathrm{G} 1$ with $32 \%$ and $17 \%$ yields, respectively, after $24 \mathrm{~h}$ of reaction at $150{ }^{\circ} \mathrm{C}$. However, in both cases, the reaction rate and selectivity (see carbon mass balance) were lower than in the case of $\mathrm{Bi}(\mathrm{OTf})_{3}$. Note that, as compared to what was observed with metal triflates, Bi(TFSI $)_{3}$ was less active than $\mathrm{Al}(\mathrm{TFSI})_{3}$ and $\mathrm{Fe}(\mathrm{TFSI})_{3}$, affording the targeted B1G1 with $35 \%$ yield only at $190{ }^{\circ} \mathrm{C}$ (entry 15). Taken together, these results show that metal triflates are more active and more selective than metal triflimidates themselves more active than metal chlorides. Among metal triflates, $\mathrm{Bi}(\mathrm{OTf})_{3}$ appears to be the most efficient one.

Next, we tried to rationalize the superior activity and selectivity of $\mathrm{Bi}(\mathrm{OTf})_{3}$. In water, few metal triflates are known to exist as an equilibrium mixture of metal triflates with metal hydroxide and triflic acid. Kobayashi classified metal triflates according to their hydrolysis constant $\left(K_{\mathrm{h}}\right){ }^{14}$ Like water, glycerol is a highly polar protic solvent and one may suspect that glycerol may lead to a glycerolysis of metal triflates inducing a partial release of triflic acid along with the formation of a metal-glycerol complex (Fig. 2).

Although $\mathrm{p} K_{\mathrm{h}}$ values provided by Kobayashi were collected in water, we observed, in a first approximation, that metal triflates with a $\mathrm{p} K_{\mathrm{h}}$ value lower than $4(\mathrm{Bi}, \mathrm{Ga}, \mathrm{In}, \mathrm{Al})$ were among the most active catalysts in this study (Table 2, entries 1-13). This result suggests that the superior activity of these metal triflates may rely on the release of triflic acid (TfOH) in glycerol. $\mathrm{Fe}$ and $\mathrm{Nd}$, which exhibit a $\mathrm{p} K_{\mathrm{h}}$ of 9.5 and 8, respectively, however appear as two exceptions (entries 6, 7). Hence, we also focused our attention on another parameter. Considering that the release of $\mathrm{TfOH}$ is initially accompanied by the formation of a metal-glycerol-based complex, we next attempted to correlate the difference of activity of metal triflates with the covalent radius of trivalent cations which is known to be a driving force in the formation of metal-glycerol complexes (templating effect). As previously observed by Djakovitch et al., glycerol was supposed to readily form a five-membered ring complex with metals. ${ }^{15}$ Formation rate and stability of these complexes are of course closely depend on the size of the cation. Interestingly, we observed that all active trivalent cations have a covalent radius lower than $2 \AA$ and preferentially lower than $1.4 \AA$ for the most active ones supporting the possible formation of a glycerol complex. We hypothesize here that metal triflates with a trivalent cation covalent radius within the range of 1.2-1.4 $\AA$ are more prone to glycerolysis and thus to the release of TfOH explaining their superior activity. Fe and $\mathrm{Nd}$ are very close to these criteria limits $\left(\mathrm{p} K_{\mathrm{h}}\right.$ and covalent

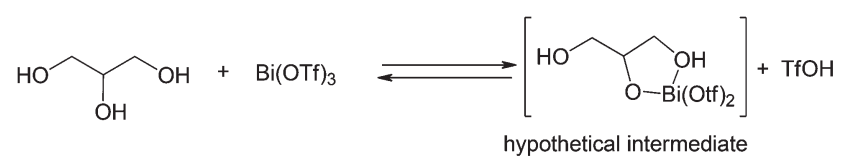

Fig. 2 Plausible glycerolysis of $\mathrm{Bi}(\mathrm{OTf})_{3}$. 
radius) and thus promote the etherification of glycerol with n-butanol with only a very moderate activity.

It is noteworthy that mono and divalent cations such as $\mathrm{Zn}$, $\mathrm{Cu}, \mathrm{Ag}$ and $\mathrm{Ca}$ are not capable of catalyzing the etherification of glycerol with $n$-butanol (entries 14-17). In particular, although $\mathrm{Zn}$ and $\mathrm{Cu}$ have an optimal $\mathrm{p} K_{\mathrm{h}}$ value and a similar covalent radius to $\mathrm{Fe}$ and $\mathrm{Nd}$, these latter were totally inefficient in pushing forward the formation of a key complex between trivalent cation and glycerol, complex which is presumably stabilized by the presence of the three hydroxyl groups of glycerol. This aspect is further supported at the end of the article where we show that replacing glycerol by a diol such as 1,2- or 1,3-propanediol led to a significant drop of the $\mathrm{Bi}(\mathrm{OTf})_{3}$ selectivity.

In order to discriminate between Lewis and Brønsted acid catalysis in the etherification of glycerol with $n$-butanol, we next carried out few counter experiments. First of all the etherification of glycerol with $n$-butanol was performed at low catalyst loading $(2.17 \mathrm{~mol} \%)$ either in the presence of $\mathrm{Bi}(\mathrm{OTf})_{3}$ or $\mathrm{TfOH}$ (Table 3). Interestingly, under these conditions, Bi(OTf $)_{3}$ was nearly two times more active than TfOH. For instance, after $24 \mathrm{~h}$ of reaction at $150{ }^{\circ} \mathrm{C}$, B1G1 were obtained with $39 \%$ yield with $\mathrm{Bi}(\mathrm{OTf})_{3}$ against $22 \%$ in the presence of $\mathrm{TfOH}$. Additionally, $\mathrm{Bi}(\mathrm{OTf})_{3}$ was found to be more selective than TfOH as illustrated by the $n$-butanol carbon mass balance

Table 3 Comparison of activity between $\mathrm{Bi}(\mathrm{OTF})_{3}$ and $\mathrm{TfOH}$ in the acid-catalyzed etherification of glycerol with $n$-butanol and the dimerization of glycerol

\begin{tabular}{lllllll}
\hline Catalyst & $\begin{array}{l}\text { Conv. } \\
\text { Gly (\%) }\end{array}$ & $\begin{array}{l}\text { Conv. } \\
\text { BuOH (\%) }\end{array}$ & $\begin{array}{l}\text { B1G1 } \\
\text { yield (\%) }\end{array}$ & $\begin{array}{l}\text { G2 } \\
\text { yield (\%) }\end{array}$ & $\begin{array}{l}\text { C \% } \\
\text { (BuOH) }\end{array}$ & $\begin{array}{l}\text { C \% } \\
\text { (Gly) }\end{array}$ \\
\hline $\mathrm{Bi}\left(\mathrm{OTf}_{3}\right)^{a}$ & 15 & 45 & 39 & 4 & 91 & 92 \\
$\mathrm{TfOH}^{a}$ & 8 & 34 & 22 & 2 & 74 & 94 \\
${\mathrm{Bi}\left(\mathrm{OTf}_{3}\right)_{3}}^{b}$ & 28 & - & - & 23 & - & 82 \\
$\mathrm{TfOH}^{b}$ & 14 & - & - & 11 & - & 79
\end{tabular}

${ }^{a}$ Glycerol $/ n$-butanol molar ratio $=4,150{ }^{\circ} \mathrm{C}, 2.17 \mathrm{~mol} \%$ of catalyst, 24 h. ${ }^{b}$ From neat glycerol, $150{ }^{\circ} \mathrm{C}, 24 \mathrm{~h}, 6.5 \mathrm{~mol} \%$ of catalyst.
(91\% vs. $74 \%$ for $\mathrm{Bi}(\mathrm{OTf})_{3}$ and $\mathrm{TfOH}$, respectively). A similar trend was observed when the catalytic reaction was conducted in neat glycerol (absence of $n$-butanol). While in the presence of $6.5 \mathrm{~mol} \%$ of $\mathrm{Bi}(\mathrm{OTf})_{3}, 28 \%$ of glycerol was converted to $23 \%$ yield of $\mathrm{G} 2$ after $24 \mathrm{~h}$ of reaction at $150{ }^{\circ} \mathrm{C}$, the reaction rate was divided by a factor of 2 when the same reaction was conducted in the presence of $6.5 \mathrm{~mol} \%$ of $\mathrm{TfOH}$ further pushing forward that $\mathrm{TfOH}$ cannot be considered as the real catalytic species.

With the aim of getting more insight into the possible role of $\mathrm{TfOH}$ in the catalytic reaction, 1,5-di-tertiobutylpyridine was added at the beginning of the reaction. This sterically hindered pyridine derivative has been reported to be capable of selectively trapping protons from a solution containing metal triflates. ${ }^{16}$ In particular, due to the presence of two sterically hindered tertiobutyl groups, this pyridine derivative is not capable of coordinating $\mathrm{Bi}(\mathrm{OTf})_{3}$. Interestingly, addition of $6.5 \mathrm{~mol} \%$ of 1,5 -di-tertiobutylpyridine at the beginning of the reaction completely inhibited the reaction showing that $\mathrm{TfOH}$ does have a significant role in the reaction mechanism. Taken together, these results suggest that the reaction mechanism is here rather complex and the formation of the real catalytic species may rely on a cooperative effect between $\mathrm{Bi}(\mathrm{OTf})_{3}$ and released TfOH. A similar phenomenon was previously observed by Le Roux and co-workers. ${ }^{17}$ At this stage, we are unfortunately not able to clarify the reaction mechanism with certitude and this aspect is now the topic of current investigations in our groups. Results will be published in due course.

Next, we tried to optimize the catalytic reaction in the presence of $\mathrm{Bi}(\mathrm{OTf})_{3}$ by varying the temperature, time, catalyst loading and glycerol $/ n$-butanol molar ratio (Table 4). An increase of the reaction temperature from $150{ }^{\circ} \mathrm{C}$ to $170{ }^{\circ} \mathrm{C}$ obviously had a beneficial effect on the conversion rate of $n$-butanol and glycerol. At $170{ }^{\circ} \mathrm{C}$, the conversion of $n$-butanol reached $89 \%$ after only 8 hours of reaction $v s .24 \mathrm{~h}$ at $150{ }^{\circ} \mathrm{C}$ (entries 2, 3). Interestingly, at such temperature, no significant change of selectivity was observed. Only a slight decrease of the $n$-butanol carbon mass balance (from $95 \%$ to $86 \%$ ) was

Table 4 Optimization of the reaction parameters in the presence of $\mathrm{Bi}(\mathrm{OTf})_{3}$

$$
\overbrace{\mathrm{OH}}^{\mathrm{OH}}+\overbrace{\mathrm{HO}}^{\mathrm{Bi}(\mathrm{OTf})_{3}} \longrightarrow \overbrace{\substack{\mathrm{OH} \\ \text { mixture of regioisomers }}}^{\mathrm{HO}}
$$

\begin{tabular}{|c|c|c|c|c|c|c|c|c|c|c|c|c|}
\hline Entry & $\begin{array}{l}\text { Catalyst } \\
\text { loading (mol\%) }\end{array}$ & $\begin{array}{l}\text { Temp. } \\
\left({ }^{\circ} \mathrm{C}\right)\end{array}$ & $\begin{array}{l}\text { Gly/BuOH } \\
\text { molar ratio }\end{array}$ & $\begin{array}{l}\text { Time } \\
\text { (h) }\end{array}$ & $\begin{array}{l}\text { Conv. } \\
\text { Gly (\%) }\end{array}$ & $\begin{array}{l}\text { Conv. } \\
\text { BuOH (\%) }\end{array}$ & $\begin{array}{l}\text { B1G1 } \\
\text { yield (\%) }\end{array}$ & $\begin{array}{l}\text { B2G1 } \\
\text { yield (\%) }\end{array}$ & $\begin{array}{l}\text { B2 } \\
\text { yield (\%) }\end{array}$ & $\begin{array}{l}\text { G2 } \\
\text { yield (\%) }\end{array}$ & $\begin{array}{l}\mathrm{C} \% \\
(\mathrm{BuOH})\end{array}$ & $\begin{array}{l}\text { C \% } \\
\text { (Gly) }\end{array}$ \\
\hline 1 & 6.5 & 120 & 4 & 72 & \multicolumn{8}{|c|}{ No reaction } \\
\hline 2 & 6.5 & 150 & 4 & 24 & 30 & 91 & 70 & 7 & 10 & 8 & 95 & 85 \\
\hline 3 & 6.5 & 170 & 4 & 8 & 29 & 89 & 64 & 3 & 10 & 9 & 86 & 86 \\
\hline 4 & 6.5 & 190 & 4 & 2 & 38 & 78 & 54 & 6 & 5 & 14 & 82 & 72 \\
\hline 5 & 6.5 & 190 & 4 & 3 & 52 & 90 & 49 & 7 & 3 & 15 & 66 & 52 \\
\hline 6 & 13.0 & 170 & 4 & 6 & 30 & 85 & 57 & 4 & 5 & 10 & 78 & 81 \\
\hline 7 & 2.2 & 170 & 4 & 10 & 22 & 70 & 40 & 2 & 11 & 5 & 76 & 69 \\
\hline 8 & 6.5 & 150 & 4 & 48 & 46 & 92 & 41 & 7 & 4 & 15 & 57 & 59 \\
\hline 9 & 6.5 & 170 & 4 & 60 & 80 & 95 & 35 & 10 & 2 & 15 & 49 & 31 \\
\hline 10 & 6.5 & 170 & 2 & 8 & 54 & 93 & 42 & 6 & 7 & 11 & 59 & 59 \\
\hline
\end{tabular}


observed. A further increase of the reaction temperature from $170{ }^{\circ} \mathrm{C}$ to $190{ }^{\circ} \mathrm{C}$ enhanced again the conversion rate since $78 \%$ of $n$-butanol was now consumed within only 2 h (entry 4 ). However, at $190{ }^{\circ} \mathrm{C}$, the glycerol carbon mass balance was significantly lowered $(72 \%)$. This effect of the reaction temperature on the glycerol mass balance was even worse (52\%) when the conversion of $n$-butanol was extended to $90 \%$ ( $3 \mathrm{~h}$, entry $5)$. Reversely, a decrease of the reaction temperature from $150{ }^{\circ} \mathrm{C}$ to $120^{\circ} \mathrm{C}$ dropped the reaction rate to an unacceptable level (entry 1). Hence, $170{ }^{\circ} \mathrm{C}$ appeared to be a good compromise between reaction rate and selectivity. One should comment that, in all cases, it was necessary to stop the reaction immediately after the total conversion of $n$-butanol. After a prolonged reaction, the yield of B1G1 indeed rapidly decreased due to their acid-catalyzed dehydration or oligomerization. This effect was of course even more pronounced when increasing the reaction temperature (entries 8, 9). We then varied the catalyst loading. Reactions were carried out at $170{ }^{\circ} \mathrm{C}$. Logically, when the catalyst loading was increased from $6.5 \mathrm{~mol} \%$ to $13 \mathrm{~mol} \%$, the reaction time was also concomitantly decreased suggesting, in a first approximation, that the reaction is not limited by diffusion problems (entry 6). Reversely, a decrease of the catalyst loading by a factor 2 obviously decreased the reaction rate (entry 7). However, in this case, the carbon mass balance was surprisingly lowered ( $62 \%$ and $34 \%$ based on $n$-butanol and glycerol, respectively) suggesting that, under these conditions, the catalytic formation of B1G1 was not the dominant reaction anymore. This unexpected change of selectivity when decreasing the catalyst loading can be attributed either to (i) the thermal instability of $\mathrm{B} 1 \mathrm{G} 1$, i.e. in this case the formation rate of B1G1 may be lower than their hypothetical thermal degradation, or (ii) a decrease of the catalyst amount mostly affects the formation rate of B1G1 as compared to other side reactions. In order to discriminate between these two hypotheses, 1 eq. of B1G1 was heated in the presence of $3 \mathrm{eq}$. of glycerol at $150{ }^{\circ} \mathrm{C}$ for $24 \mathrm{~h}$ without the addition of any catalyst. Under these conditions, B1G1 were stable suggesting that this decrease of selectivity cannot be attributed to the thermal degradation of B1G1. From this result, one may conclude here that a decrease of the catalyst loading affects the etherification of glycerol with $n$-butanol to a greater extent than other side reactions such as B1G1 and glycerol oligomerization or dehydration for instance. Hence, a catalyst loading of $6.5 \mathrm{~mol} \%$ appears to be a good compromise.

Next, we investigated the influence of the glycerol $/ n$-butanol molar ratio on the selectivity to B1G1. A decrease of the glycerol $/ n$-butanol molar ratio from 4 to 2 did not dramatically change the reaction rate (entry 10). The carbon mass balance was however lowered presumably due to the formation of polyetherified glyceryl adducts that are unfortunately difficult to detect and quantify using our analytical method.

In Fig. 3 is plotted the formation of B1G1 as a function of reaction time at $150^{\circ} \mathrm{C}, 170{ }^{\circ} \mathrm{C}$ and $190^{\circ} \mathrm{C}$. From this figure, it is interesting to note that, in all cases, the yield of B1G1 did not reach a plateau suggesting that (1) the catalyst was still

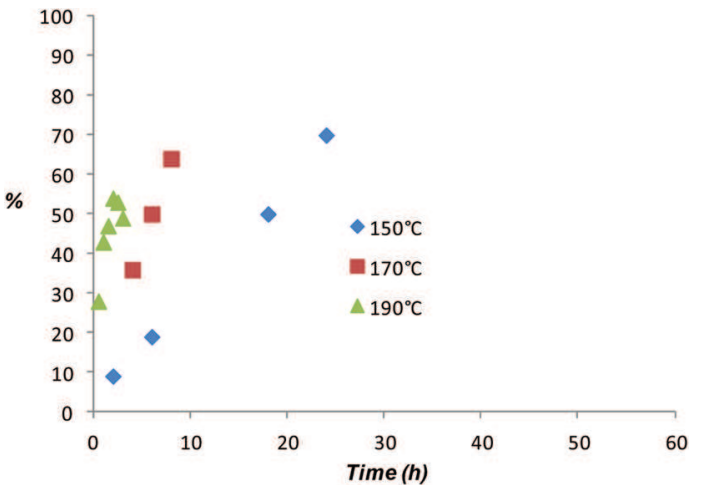

Fig. 3 Yields of $\mathrm{B} 1 \mathrm{G} 1$ vs. reaction time at $150{ }^{\circ} \mathrm{C}, 170^{\circ} \mathrm{C}$ and $190^{\circ} \mathrm{C}$.

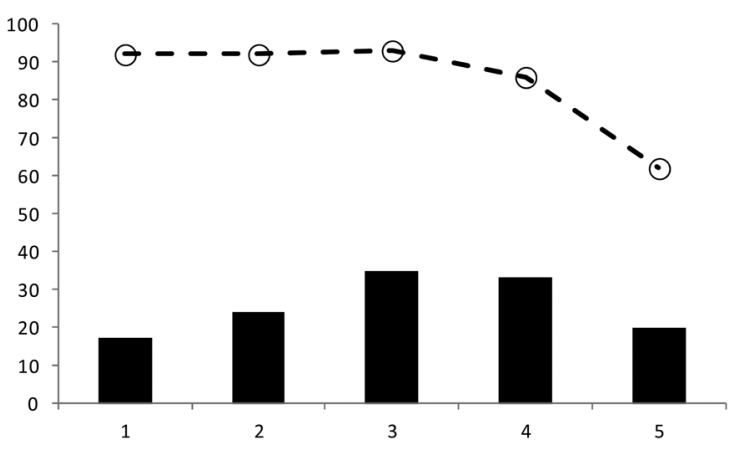

Fig. 4 Cumulative yield of monobutylglyceryl ethers calculated on the basis of glycerol after four consecutive additions of $n$-butanol and 0 carbon mass balance based on glycerol.

active and (2) an extra amount of $n$-butanol can be added at the end of the reaction.

To this end, after completion of the reaction, an extra amount of $n$-butanol was directly added to the reaction media. The amount of added $n$-butanol was adjusted in order to maintain a (remaining) glycerol $/ n$-butanol molar ratio of 4 . Interestingly, when using this procedure, the yield of B1G1 (determined on the basis of $n$-butanol) remained constant after three consecutive additions and obviously gradually increased from $18 \%$ to $35 \%$ when the yield was calculated on the basis of glycerol (Fig. 4).

These results show that, under these conditions, the catalyst is stable. However, after the fourth addition of $n$-butanol, the selectivity to B1G1 started to drop and, in this case, the conversion rate of B1G1 (dehydration, oligomerization) becomes the dominant reaction as supported by the measurement of the carbon mass balance.

Considering that $\mathrm{TfOH}$ has a significant activity in the etherification of glycerol with $n$-butanol, we then screened the catalytic activity of Brønsted acid catalysts in order to compare them with $\mathrm{Bi}(\mathrm{OTf})_{3}$. All reactions were performed in the presence of $6.5 \mathrm{~mol} \%$ of Brønsted acid and heated at $150{ }^{\circ} \mathrm{C}$ for $24 \mathrm{~h}$ (Table 5). For all the tested Brønsted acids, the yield of B1G1 was lower $(46-56 \%)$ than in the case of $\mathrm{Bi}(\mathrm{OTf})_{3}$. In 
Table 5 Catalytic etherification of glycerol with $n$-butanol in the presence of Brønsted acid catalysts or base catalysts ${ }^{a}$

\begin{tabular}{|c|c|c|c|c|c|c|c|c|c|}
\hline Entry & Catalyst & $\begin{array}{l}\text { Conv. } \\
\text { Gly (\%) }\end{array}$ & $\begin{array}{l}\text { Conv. } \\
\text { BuOH (\%) }\end{array}$ & $\begin{array}{l}\text { B1G1 } \\
\text { yield (\%) }\end{array}$ & $\begin{array}{l}\text { B2G1 } \\
\text { yield (\%) }\end{array}$ & $\begin{array}{l}\text { B2 } \\
\text { yield (\%) }\end{array}$ & $\begin{array}{l}\mathrm{G} 2 \\
\text { yield (\%) }\end{array}$ & $\begin{array}{l}\mathrm{C} \% \\
(\mathrm{BuOH})\end{array}$ & $\begin{array}{l}\text { C \% } \\
\text { (Gly) }\end{array}$ \\
\hline 1 & $\mathrm{TfOH}$ & 39 & 84 & 60 & 6 & 6 & 15 & 86 & 78 \\
\hline 3 & $\mathrm{MSA}^{c}$ & 45 & 90 & 56 & 0 & 4 & 22 & 67 & 80 \\
\hline 4 & $\mathrm{H}_{2} \mathrm{SO}_{4}$ & 46 & 89 & 46 & 0 & 7 & 12 & 60 & 51 \\
\hline 5 & Bet $\cdot \mathrm{HCl}^{d}$ & 8 & 6 & 2 & 0 & 0 & 0 & 33 & 6 \\
\hline 6 & Bet $\cdot \mathrm{H}_{2} \mathrm{SO}_{4}{ }^{d}$ & 0 & 0 & 0 & 0 & 0 & 0 & 0 & 0 \\
\hline
\end{tabular}

${ }^{a}$ Glycerol $/ n$-butanol molar ratio $=4,150{ }^{\circ} \mathrm{C}, 6.5 \mathrm{~mol} \%$ of catalyst, $24 \mathrm{~h} .{ }^{b}$ Dodecylbenzene sulfonic acid. ${ }^{c}$ Methanesulfonic acid. ${ }^{d}$ Bet $=$ $\left(\mathrm{CH}_{3}\right)_{3} \mathrm{~N}^{+}\left(\mathrm{CH}_{2}\right)\left(\mathrm{COO}^{-}\right) .{ }^{e}$ Bis(trifluoromethane)sulfonimide acid.

particular, $\mathrm{H}_{2} \mathrm{SO}_{4}$ was poorly selective and favours intramolecular dehydration reactions. Note that betain-hydrochloride and betaïn hydrogenosulfate were found ineffective in the etherification of glycerol with $n$-butanol, presumably due to either their lower acidity as compared to other tested Brönsted acids or their ability to form a deep eutectic mixture with glycerol, thus lowering the acid strength of the carboxylic group (entries 5,6$).^{18}$ Note that no esterification reaction with glycerol was evidenced. Although triflimidic acid $\left(\mathrm{HN}\left(\mathrm{O}_{2} \mathrm{SCF}_{3}\right)_{2}\right.$, TFSI) was less active than $\mathrm{Bi}(\mathrm{OTf})_{3}(56 \%$ of $\mathrm{B} 1 \mathrm{G} 1$ with TFSI $v s$. $70 \%$ with $\mathrm{Bi}(\mathrm{OTf})_{3}$ after $24 \mathrm{~h}$ of reaction), this Brønsted acid catalyst was as selective as $\mathrm{Bi}(\mathrm{OTf})_{3}$ to alkyl glyceryl ethers $(87 \%, \mathrm{~B} 1 \mathrm{G} 1+\mathrm{B} 2 \mathrm{G} 1)$ and the carbon mass balance remained higher than $93 \%$.

Basic catalysts such as $\mathrm{NaOH}, \mathrm{K}_{2} \mathrm{CO}_{3}$ and TBD, which are also known to catalyze the oligomerization of glycerol, were also tested. ${ }^{19}$ However, within a range of temperature of $150-200{ }^{\circ} \mathrm{C}$, formation of B1G1 did not take place and only unidentified products were observed at $200{ }^{\circ} \mathrm{C}$ (entries 8-10).

Having all these results in hand, we then examined the scope of this route not only to determine the limit of this methodology but also to get more insight into the unprecedented selectivity observed in the presence of $\mathrm{Bi}(\mathrm{OTf})_{3}$ (Table 6). First of all, we tested the etherification of glycerol with alkyl alcohols with a longer chain length such as $n$-pentanol and $n$-hexanol. Reactions were conducted at $150{ }^{\circ} \mathrm{C}$ in the presence of $6.5 \mathrm{~mol} \%$ of $\mathrm{Bi}(\mathrm{OTf})_{3}$. In accordance with our previous report, ${ }^{11 b}$ we observed a decrease of the catalyst activity with an increase of the chain length presumably due to an increase of the alkyl alcohol hydrophobicity making its coupling with glycerol (highly polar molecule) more difficult. As a result, after $24 \mathrm{~h}$ of reaction at $150{ }^{\circ} \mathrm{C}$, the yield of alkyl glyceryl ethers dropped from $70 \%$ to $50 \%$ and then to $32 \%$ when going from $n$-butanol to $n$-pentanol and $n$-hexanol, respectively. However, the carbon mass balance (based on glycerol) remained higher than $91 \%$ further confirming the high selectivity of $\mathrm{Bi}(\mathrm{OTf})_{3}$ in such reactions.

In the presence of $n$-butanol, $\mathrm{Bi}(\mathrm{OTf})_{3}$ was also capable of catalyzing the etherification of 1,2-propanediol. At $150{ }^{\circ} \mathrm{C}$, monobutylethers of 1,2-propanediol were obtained with $46 \%$ yield. The regioselectivity of the reaction was $7 / 3$ in favour of the etherification in the primary hydroxyl group. Surprisingly,
Table 6 Acid-catalyzed etherification of various polyols in the presence of $\mathrm{Bi}$ $(\mathrm{OTf})_{3}{ }^{a}$

\begin{tabular}{|c|c|c|c|c|}
\hline Polyol & $\begin{array}{l}\text { Alkyl } \\
\text { alcohol }\end{array}$ & $\begin{array}{l}T \\
\left({ }^{\circ} \mathrm{C}\right)\end{array}$ & $\begin{array}{l}\text { Time } \\
\text { (h) }\end{array}$ & $\begin{array}{l}\text { Monoether } \\
\text { yield }^{b}(\%)\end{array}$ \\
\hline & $n$-Pentanol & 150 & 24 & 50 \\
\hline & $n$-Hexanol & 150 & 24 & 32 \\
\hline & $n$-Butanol & 150 & 24 & 46 \\
\hline $\mathrm{HO}^{-}$ & $n$-Butanol & 170 & 32 & 41 \\
\hline & $n$-Butanol & 150 & 48 & 38 \\
\hline
\end{tabular}

${ }^{a}$ Glycerol $/ n$-alkyl alcohol molar ratio $=4,6.5 \mathrm{~mol} \%$ of catalyst. ${ }^{b} \mathrm{GC}$ yield.

the reaction was more difficult from 1,3-propanediol since, in this case, we had to increase the reaction temperature to $170{ }^{\circ} \mathrm{C}$. Under these conditions, $41 \%$ yield of monoether was produced after $32 \mathrm{~h}$ of reaction. Under similar conditions, tris (hydroxymethyl)ethane was also converted to the desired monobutylether with $38 \%$ yield. As observed with glycerol, prolonged reaction time after $90 \%$ conversion of $n$-butanol led to a drop of the monoether selectivity. Although we have no rational explanation yet, we would like to point out here that, in the presence of $\mathrm{Bi}(\mathrm{OTf})_{3}$, oligomerization of 1,2-propanediol, 1,3-propanediol and tris(hydroxymethyl)ethane was more favourable than from glycerol, explaining the lower yield of monobutylethers obtained with these polyols and reinforcing the key role that it may play in the hypothesized complex biglycerol described above.

Finally, we investigated the potential of this methodology from sorbitol, a valuable polyol obtained after hydrogenation of glucose (Fig. 5). To our delight, when neat sorbitol was heated at $150{ }^{\circ} \mathrm{C}$ for $16 \mathrm{~h}$ in the presence of $3.6 \mathrm{~mol} \%$ of $\mathrm{Bi}(\mathrm{OTf})_{3}$, the dehydrative intramolecular cyclisation of sorbitol to isosorbide ( $85 \%$ yield) selectively took place. Next, using the same conditions to those described in Table 6, isosorbide can 


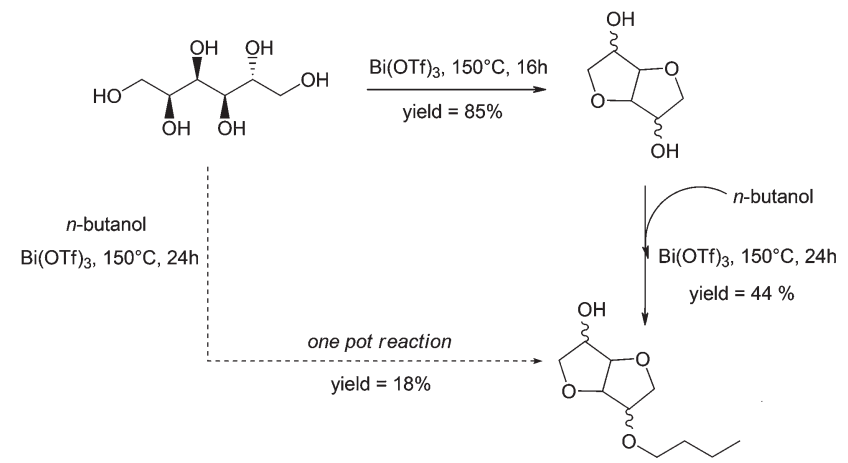

Fig. 5 Catalytic dehydrative intramolecular cyclisation of sorbitol to isosorbide and its subsequent etherification with $n$-butanol $\left(13 \mathrm{~mol} \%\right.$ of $\mathrm{Bi}(\mathrm{OTf})_{3}$, isosorbide $/ n$-butanol molar ratio $=4 / 1$ )

be etherified with $n$-butanol affording the monobutylether of isosorbide with $44 \%$ yield which is a similar yield to those obtained from 1,2-propanediol, 1,3-propanediol and tris(hydroxymethyl)ethane. Note that the one pot conversion of sorbitol to the desired monobutylether of isosorbide is a feasible route but the yield of the reaction remained rather low (18\%) and formation of unidentified side products was observed. Such a result might be due to the difference of kinetics between the two steps, isosorbide being much less stable than sorbitol in our experimental conditions.

\section{Conclusions}

We report here that Lewis acids such as metal triflates, and especially $\mathrm{Bi}(\mathrm{OTf})_{3}$, are capable of catalyzing the etherification of glycerol with $n$-butanol with an unprecedented selectivity. Under optimized conditions, up to $70 \%$ yield of B1G1 was obtained while the carbon mass balance determined on glycerol and $n$-butanol remained higher than $85 \%$. By comparison, all tested Brønsted or Lewis acids are less active and less selective, showing the attractiveness of metal triflates in such reactions. Although elucidation of the reaction mechanism clearly deserves deeper investigations, we show here, by means of different counter experiments, that the surprising selectivity observed with $\mathrm{Bi}(\mathrm{OTf})_{3}$ may rely on a synergistic effect between $\mathrm{Bi}(\mathrm{OTf})_{3}$ and triflic acid that may be released by glycerolysis of $\mathrm{Bi}(\mathrm{OTf})_{3}$. This aspect is the topic of current investigations in our group and should be published in a couple of months.

\section{Notes and references}

1 Published by Transparency Market Research (http://www. transparencymarketresearch.com) "Specialty Surfactants Market - Global Scenario, Raw Material and Consumption Trends, Industry Analysis, Size, Share \& Forecast 2011-2017".
2 For selected comprehensive reviews please see: (a) A. Corma, S. Iborra and A. Velty, Chem. Rev., 2007, 107, 2411-2502; (b) P. Y. Dapsens, C. Mondelli and J. PerezRamirez, ACS Catal., 2012, 2(7), 1487-1499; (c) P. Gallezot, Chem. Soc. Rev., 2012, 41(4), 1538-1558.

3 P. Foley, A. Kermanshahi pour, E. S. Beach and J. B. Zimmerman, Chem. Soc. Rev., 2012, 41, 1499-1518.

4 U. Biermann, U. Bornscheuer, M. A. R. Meier, J. O. Metzger and H. J. Schäfer, Angew. Chem., Int. Ed., 2011, 50(17), 3854-3871.

5 A wide range of patents are available mainly from TAIYO KAGAKU KK and DAICEL CHEM in recent years.

6 (a) A. Behr and M. Urschey, Adv. Synth. Catal., 2003, 345, 1242-1246; (b) A. Behr, J. Leschinski, C. Awungacha, S. Simic and T. Knoth, ChemSusChem, 2009, 2, 71-76.

7 (a) R. Palkovits, I. Nieddu, R. J. M. Klein Gebbink and B. Weckhuysen, ChemSusChem, 2008, 1, 193-196; (b) R. Palkovits, I. Nieddu, C. A. Kruithof, R. J. M. Klein Gebbink and B. Weckhuysen, Chem.-Eur. J., 2008, 14, 8995-9005; (c) R. Palkovits, A. N. Parvulescu, P. J. C. Hausoul, C. A. Kruithof, R. J. M. Klein Gebbink and B. Weckhuysen, Green Chem., 2009, 11, 1155-1160; (d) P. Hausoul, J. C. Parvulescu, N. Andrei, M. Lutz, A. L. Spek, P. C. A. Bruijnincx, R. J. M. Klein Gebbink and B. M. Weckhuysen, ChemCatChem, 2011, 3(5), 845-852; (e) P. Hausoul, P. A. Bruijnincx, R. J. M. Klein Gebbink and B. M. Weckhuysen, ChemSusChem, 2009, 2(9), 855-858.

8 (a) L. Conceicao, R. Bogel-Lukasik and E. Bogel-Lukasik, Green Chem., 2012, 14(3), 673-681; (b) J. M. Lopes, Z. Petrovski, R. Bogel-Lukasik and E. Bogel-Lukasik, Green Chem., 2011, 13(8), 2013-2016; (c) S. Bigot, J. Lai, I. Suisse, M. Sauthier, A. Mortreux and Y. Castanet, Appl. Catal., A, 2010, 382(2), 181-189; (d) A. Gordillo, L. Durán Pachón, E. de Jesus and G. Rothenberg, Adv. Synth. Catal., 2009, 351(3), 325-330.

9 (a) Y. Shi, W. Dayoub, A. Favre-Réguillon, G.-R. Chen and M. Lemaire, Tetrahedron Lett., 2009, 50, 6891-6893; (b) Y. Shi, W. Dayoub, G.-R. Chen and M. Lemaire, Green Chem., 2010, 12, 2189-2195; (c) M. Sutter, W. Dayoub, E. Metay, Y. Raoul and M. Lemaire, ChemSusChem, 2012, 5, 2397-2409.

10 As representative articles please see: (a) K. Klepacova, D. Mravec and M. Bajus, Chem. Pap., 2006, 60, 224; (b) K. Klepacova, D. Mravec and M. Bajus, Appl. Catal., A, 2005, 294, 141-147; (c) Y. Gu, A. Azzouzi, Y. Pouilloux, F. Jérôme and J. Barrault, Green Chem., 2008, 10, 164-167; (d) R. Luque, V. Budarin, J. H. Clark and D. J. Macquarrie, Appl. Catal., B, 2008, 82, 157-162.

11 (a) P. Gaudin, R. Jacquot, P. Marion, Y. Pouilloux and F. Jérôme, Catal. Sci. Technol., 2011, 1, 616-620; (b) P. Gaudin, R. Jacquot, P. Marion, Y. Pouilloux and F. Jérôme, ChemSusChem, 2011, 4(6), 719-722; (c) S. Pariente, N. Tanchoux and F. Fajula, Green Chem., 2009, 11, 1256-1261. 
12 As a selected review please see: M. E. Zakrzewska, E. BogelLukasik and R. Bogel-Lukasik, Chem. Rev., 2011, 111(2), 397-417.

13 S. Antoniotti, V. Dalla and E. Dunach, Angew. Chem., Int. Ed., 2010, 49, 7860-7888.

14 (a) S. Kobayashi and K. Manebe, Acc. Chem. Res., 2002, 35, 209-217; (b) S. Kobayashi and C. Ogawa, Chem.-Eur. J., 2006, 12, 5954-5960; (c) S. Kobayashi, M. Ueno and T. Kitanosono, Top. Curr. Chem., 2012, 311, 1-17.

15 J. Chaminand, L. Djakovitch, P. Gallezot, P. Marion, C. Pinel and C. Rosier, Green Chem., 2004, 6, 359-361.

16 (a) R. F. Lambert, R. J. Hinkle, S. E. Ammann, Y. Lian, J. Liu, S. E. Lewis and R. D. Pike, J. Org. Chem., 2011, 76,
9269-9277; (b) T. C. Wabnitz, J.-Q. Yu and J. B. Spencer, Chem.-Eur. J., 2004, 10, 484-493.

17 (a) O. Mouhtady, H. Gaspard-Iloughmane, N. Roques and C. Le Roux, Tetrahedron Lett., 2003, 44, 6379-6382; (b) M. Peyronneau, M. Boisdon, N. Roques, S. Mazieres and C. Le Roux, Eur. J. Org. Chem., 2004, 4636-4640; (c) J. M. Bothwell, S. W. Krabbez and R. S. Mohan, Chem. Soc. Rev., 2011, 40, 4649-4707.

18 (a) Q. Zhang, K. De Oliveira Vigier, S. Royer and F. Jérôme, Chem. Soc. Rev., 2012, 41, 7108-7146; (b) K. De Oliveira Vigier, A. Benguerba, J. Barrault and F. Jérôme, Green Chem., 2012, 14, 285-289.

19 J. Barrault, Y. Pouilloux, J.-M. Clacens, C. Vanhove and S. Bancquart, Catal. Today, 2002, 75, 177-181. 